\title{
Open and Networked Education: Learning the future of learning
}

\author{
Elisabete Barros ${ }^{1, a}$, António José Osório ${ }^{1, b}$ \\ ${ }^{1}$ Institute of Education, University of Minho, Campus de Gualtar, 4710-057 Braga, Portugal; \\ abarros.viana@gmail.com, bajosorio@ie.uminho.pt
}

Keywords: Disruptive innovation, Educational scenarios, School of the future, Digital educational resources.

\begin{abstract}
The analysis about Education and current educational settings (or educative technological contexts) leads to the need for reflection and study on the state of school as a public space and on their role in relation to the promotion and development of skills of children and youth, either at European or international levels. To understand the future of education there are multiple lines of analysis, as well as several authors speculating about the school's future and the future of this young technological society. In this paper we intend to discuss the state of the art about the school of the future and reflect on possible connections, developed under a doctoral project in Portugal, reflecting about some of these central issues.
\end{abstract}

\section{Introduction}

This research was motivated by a constant desire to understand the world around us, especially the educational world, so important in our lives because we spend much of our time in it and it affects some of our future decisions. We are concerned about the future of our children and the conditions of the 21th century schools. Why educational settings remain so similar to the school of hundred fifty years ago, while society, economy, knowledge and communication has changed? Certainly, in fifty years it will be different. This work presents a brief reflection about the construction of educational scenarios of the future, through the analysis of some contemporary movements.

\section{Learning the future of learning}

State of art. The use of digital technologies for children and youth has been growing as well as its application in learning whether in formal, non-formal or informal sceneries. Computers and the internet have made numerous changes at all levels, and in the educational scenario we see them as responsible for the need for the reinvention of school or, as suggested by Silva [1], a strategy for renewal.

The presence of home technology is progressing around the world [2], emerging the need to study, think and discuss about their inclusion, impact and side effects because all the technology that solves a particular problem tends to cause others. In reviewing the literature we found related concerns, such as, digital rights of children and youth [3], internet security [4, 5, 6] or health implications [7].

At school, this presence is also growing and there are numerous initiatives and technological projects, that respond under the banner of improving the quality of education. We observe plans for computers in schools in various settings: One Laptop per Child, in the United States [8, 9]; Programa Um Computador por Aluno ${ }^{1}$, in Brasil; the Technological Plan for Education, with the initiative e-escolinhas ${ }^{2}$ and the Magalhães Computer, in Portugal and expanding to other Latin American countries. Currently, in Europe, under the project Future Classroom Lab [10] experiences are emerging as well as movements related to the future classroom. Focusing special attention on the organization of educational space, the Future Classroom Lab project was already implemented in eleven Portuguese schools [10].

\footnotetext{
${ }^{1}$ One Laptop per Child Programme

${ }^{2}$ Rough translation: e-small schools
} 
Internationally, there are several relevant initiatives and relevant schools to this discussion: School in the Cloud [11], ALT School, Vittra Telefonplan School, Khan Academy, Saunalahti School and many others. This technological presence creates new connections between school and home as suggested by Livingstone and Sefton-Green [12] and those issues need to be addressed.

The literature suggests different readings on the effects of the use of technology in education. Some results display improvements in teaching and learning after use [13, 14], although specific technology for a particular purpose. On the other hand, Falck et al. [15] refer different relationships depending on the subject area, suggesting the idea of positive results when we seek ideas and information, but negative when related skills and procedures. Still, the OECD report [2] refers consequences in terms of relationship learning and school, alluding that the limited use of computers in school is better than non-use, but the use of higher times is associated with inferior results.

Selwyn [16] introduces important issues on education and technology, pondering the effect of technology in learning. Dias [17] suggests that the great innovation is not the instruments but the network of relationships that are generated in the practices and interactions between the various actors. Mattila and Silander [18] propose changes at five levels: leadership, education, capacity building, technology and architecture.

The importance of research about the future school field is unquestionable. Today, we experience other needs, other realities, other contexts and as advocates Nóvoa [19], we have to reinvent the school with the same intensity, progressing to the thought of an education we have created for ourselves [20], involved in a network of relationships [17].

Methodology. The research developed in the past years led us to conclude that despite the emergence of digital and technological resources in educational environments, pedagogical models tend to follow traditional models, so there still is a long way to go at cultural, educational and technical level; the use of technology and digital educational resources in the classroom increases the students' motivation levels, however, data on the actual effects on learning are still scarce and fragile [21]. In this context, the question that arises is not how we can use technology to promote students learning, but how to educate in emerging contexts of educational innovation for learning and networking knowledge, leading us to rethink and reinvent education for the future. The presence of technology actually helps or disturbs learning in the classroom?

In this first year of study, following a mixed methods research design, we aim to involve children, parents, educators, teachers and other stakeholders related to the development of young children in new scenarios of learning and network training, in a perspective of learning to learn collaboratively, transposing individual knowledge to collective knowledge. In an open education and network perspective we aim to observe the nodes and the network links from the interaction provided by the future learning spaces and study the implications and changes in ways of thinking, of thinking about education and teaching practices.

The work plan is organized in three main activities: i) study and planning; ii) implementation and experimentation; iii) analysis and discussion. At each stage specific methodologies will be applied. In the first activity will be consider four step: 1) the state of art, drawing a long-term plan, using the systematic review methodology literature [22];2) planning of work strategies and research, supported by the reading of the most recent and innovative experiences, preparing checklists, registration target selection possibilities, using document management methodologies and information; 3) the achievement of three case studies, target selection among the many possibilities, taking into account characteristics of emerging and innovative learning environments; 4) following the Delphi methodology [23, 24], we will consult a group of experts in the field of Education and Technology about the school of the future. The goal will be to discuss future scenarios of educational innovation, the development of enriched environments and gather indicators, procedures and strategies for the reinvention of the future school.

After the study and deep reflection on the theme, we consider ourselves prepared to proceed to the second and third activities: creation of the learning scenario with futuristic perspectives, taking into consideration the present-day and the needs of today's students. This activity provides the tasks related to creating a learning environment with innovative features aimed at children between 10 and 
15 years of age, relying on participatory methodologies $[25,26]$ and mosaic approach [27]. In this activity we will fit the construction and validation of research and evaluation instruments appropriate to the context in question. The collected data will be essentially qualitative, although there may be quantitative data. During this period all the tasks will be supported by the use of specific tools for analysis and data processing.

Expectations. In conclusion, we intend to follow up the design of educational scenarios of the future and study new ways of networked learning and teaching. This research project which undergoes its first year of work and aims: i) to study new innovative pedagogical scenarios; ii) to gather relevant information to define indicators for change and pedagogical innovation in the emerging environment of open education and networking; and, if possible, iii) to create educational scenarios for future education. We believe that, in the 21 st century, learning is a customizable process and in our draft methodology we want to bring the school for this new universe, making it more open to individual representations of each individual student, allowing him/her to build his/her own knowledge according to individual personal characteristics, believing that it is possible to create a basic structure for the construction of imagery representations of each individual in the network of relationships.

\section{Final considerations}

Following the current discussion of the school of the future, we intend to contribute originally to the contemporary educational debate by collecting indicators and key strategies in the construction of new learning scenarios involving children and experts, focusing learning in the current digital society and the network relations [17]. It is imperative to reflect on the role of schools in the digital society, assuming its importance as a place that creates culture and citizenship.

\section{References}

[1] B. Silva, A tecnologia é uma estratégia para a renovação da escola, Movimento, 5 (2002) 28-44. Revista da Faculdade de Educação da Universidade Federal Fluminense, Tecnologia, Comunicação e Educação, Rio de Janeiro, Brasil.

[2] OECD, Students, computers and learning: Making the connection, PISA, OECD Publishing, (2015).

[3] S. Livingstone, G. Mascheroni, M. Dreier, S. Chaudron and K. Lagae, How parents of young children manage digital devices at home: The role of income, education and parental style, LSE, London, EU Kids Online, (2015).

[4] A.F. Monteiro, "Tem é de ser de mim": novas tecnologias, riscos e oportunidades na perspetiva das crianças, Institute of Education of University of Minho, (2014).

[5] T.S.P.D. Castro, "It's a complicated situation". Harm in everyday experiences with technology. A qualitatitve study with school-aged children, Institute of Education of University of Minho, (2015).

[6] Internet Segura, Centro Internet Segura - Annual Report 2015, (2015). Information on http://www.internetsegura.pt/sites/default/files/Public\%20Annual\%20Report\%202015.pdf

[7] A. Dâmaso, M. Garcia, F. Paulas, I. Silva and F. Vaz, Quotidiano digital: A influência da internet na saúde das crianças e dos adolescentes, Percursos, 26 (2012) 23-29.

[8] H. Lopes (Rel.), Relatório de resultados do inquérito aos alunos sobre o Plano Tecnológico da Educação, Lisbon, Universidade Católica Portuguesa, Observatório do Plano Tecnológico da Educação, (2010).

[9] M. Warschauer, S.R. Cotton and M.G. Ames, One laptop per child Birmingham: Case study of a radical experiment, International Journal of Learning and Media, 3(2) (2012) 61-76. Massachusetts Institute of Technology, doi: 10.1162/IJLM_a_00069

[10] A.P.A. Alves, C.V. Ferreira, R.A. Ribeiro, A.R.Z. Machado and A.C.C.S.V. Barbosa, Laboratórios de aprendizagem: Cenários e histórias de aprendizagem. Iniciativa "Laboratórios de Aprendizagem (PT) / Future Classroom Lab (EUN), (2015). 
[11] S. Mitra, S. Kulkarni, J. Stanfield, Learning at the Edge of Chaos - Self-Organising Systems in Education, in: H. E. Lees, N. Noddings (Eds.), The Palgrave International Handbook of Alternative Education, London, UK, Palgrave Macmillan, 2016.

[12] S. Livingstone, J. Sefton-Green, The class: Living and learning in the digital age, New York, New York University Press, (2016).

[13] R. R. Ribeiro, A tecnologia no processo ensino-aprendizagem, Universidade Federal de Santa Catarina, Centro Tecnológico, (2003).

[14] J. Machado, B.D. Silva and L.S. Almeida, Ensino-aprendizagem com recurso à tecnologia informática: mudanças observadas nos alunos, in: A. Barca, M. Peralbo, A. Porto, B. D. Silva and L.S. Almeida (Eds.), Actas do IX Congresso Internacional Galego-Português de Psicopedagoxía, Corunha, University of Corunha, 2007, pp. 652-663.

[15] Falck, C. Mang and L. Woessmann, Virtually no effect? Different uses of classroom computers and their effect on student achievement, IZA Discussion Paper, 8939, (2015).

[16] N. Selwyn, Education and technology: Key issues and debates, London, Bloomsbury, (2011).

[17] P. Dias, Comunidades de educação e inovação na sociedade digital, Educação, Formação \& Tecnologias, 5 (2) (2012) 4-10.

[18] P. Mattila, P. Silander (Eds.), How to create the school of the future: Revolutionary thinking and design from Finland, Oulu, University of Oulu, Center for Internet Excellence, (2015).

[19] Information on https://www.youtube.com/watch? $\mathrm{v}=$ UNoodQPas0o

[20] S. Downes, Connectivism and Connective Knowledge. Essays on meaning and learning networks (2012).

[21] E. Barros, A.J. Osório, A. Ramos, C. Moreira and L. Gonçalves, Digital educational resources: The case of Manual Digital II, Multimedia Technology, 3 (2014) 14-22.

[22] D. Gough, S. Oliver and J. Thomas (Eds.), An introduction to systematic reviews, London, Sage, (2012).

[23] M. Adler, E. Ziglio (Eds.), Gazing into the Oracle: The Delphi method and its application to social policy and public health, London, Kingsley Publishers, 1996.

[24] C.C. Hsu, B.A. Sandford, The Delphi technique: Making sense of consensus, Practical assessment research \& evaluation, 12(10) (2007) 1-8.

[25] J. Boyden, J. Ennew, Children in focus: A manual for participatory research with children, Stockholm, Radda Barnen, 1997.

[26] C. O'Kane, The development of participatory techniques. Facilitating children's views about decisions which affect them, in: P. Christensen, A. James (Eds.), Research with children. Perspectives and practices, pp. 136-159, RoutledgedFalmer, (2003).

[27] A. Clark, P. Moss, Listening to young children: The mosaic approach, United Kingdom, JKP, 2001. 